\title{
Bioakumulasi Logam Berat Merkuri (Hg) Di Musim Hujan Pada Budidaya Kerang Hijau (Perna viridis) Di Perairan Cirebon, Jawa Barat
}

\section{Bioaccumulation Of Heavy Metal Mercury (Hg) In Rain Season In Culture Of Green Mussel (Perna viridis) On Cirebon Water, West Java}

Dewi Nurhayati*, Didha Andini Putri

Fakultas Perikanan dan Ilmu Kelautan Universitas 17 Agustus 1945 Cirebon

Jl. Perjuangan No. 17 BY PASS CIREBON 45132 (0231) 486622 FAX. 90231)

*Email : dewinurhayati24@gmail.com

\begin{abstract}
Abstrak
Penelitian ini bertujuan untuk mengetahui bioakumulasi dari logam berat merkuri (Hg) pada kerang hijau, sedimen, dan air pada budidaya kerang hijau di perairan Cirebon, Jawa Barat pada musim hujan yaitu bulan Februari 2018. Sedimen, kerang hijau P. viridis, dan air diambil dari tempat budidaya kerang hijau perairan bondet Cirebon. Sampel diambil pada musim hujan dibulan Februari pada usia panen yaitu usia 6 bulan pemeliharaan. Sampel air laut, sedimen dan kerang hijau diambil sebanyak 3 kali ulangan. Pengujian logam berat merkuri (Hg) mengikuti SNI 01-2354.6-2006 diukur di laboratorium Balai Pengujian dan Pembinaan Mutu Hasil Perikanan (BPPMHP) Cirebon, Jawa Barat. Berdasarkan hasil penelitian, diketahui bahwa kandungan logam berat merkuri (Hg) pada sedimen

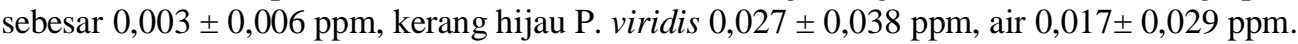

Kata kunci : Kerang hijau, logam berat merkuri, musim hujan, perairan Cirebon

\begin{abstract}
A Study was conducted to determine the bioaccumulation of heavy metal mercury $(\mathrm{Hg})$ by the tissue of Perna viridis (green mussel), water, and sediment collected from culture of green mussel in Cirebon water, West Java on rainy season February 2018. Sediments, green shells of P. viridis, and water were taken from the culture of green mussel of Cirebon waters. Samples were taken during the rainy season in February at harvest age ie 6 months of maintenance. Seawater, sediment, and green shell samples were taken 3 replications. Testing of mercury (Hg) heavy metals follows SNI 01-2354.6-2006 measured in the laboratory of Research and Development Guidance of Quality of Fishery Products (BPPMHP) Cirebon, West Java. Based on the results of the research, it is known that the content of heavy metals mercury $(\mathrm{Hg})$ in sediments of $0.003 \pm 0.006 \mathrm{ppm}$, green mussel P. viridis $0.027 \pm 0.038$ ppm, water $0.017 \pm 0.029 \mathrm{ppm}$.
\end{abstract}

Keywords: Green mussel, heavy metal mercury, rainy season, Cirebon water 


\section{PENDAHULUAN}

Kerang hijau Perna viridis merupakan salah satu komoditi perikanan di perairan Cirebon yang banyak digemari oleh masyarakat. Selain kandungan gizinya yang cukup tinggi, harganya pun murah meriah dibandingkan ikan atau kepiting. Namun demikian kerang hijau juga merupakan komoditi perikanan yang dapat mengakumulasi logam berat dalam jumlah yang tinggi. Pada tahun 2016, diketahui bahwa terdapat korban jiwa pada beberapa warga di wilayah Kecamatan Pantai Kabupaten Cirebon dan sebagian lagi banyak yang mengalami keracunan akibat mengkonsumsi kerang hijau yang diduga telah tercemar logam berat (Supriadi, 2016).

Logam berat merupakan zat yang berbahaya dan beracun jika jumlahnya melebihi ambang batas. Logam berat merkuri (Hg) adalah logam non essensial bagi tubuh, karena bersifat toksik dalam jumlah sedikit.(Türkmen et al., 2008). Tingginya kandungan logam berat pada komoditi perikanan disebabkan oleh lingkungan perairan yang telah tercemar oleh limbah. Logam berat akan terdistribusi di berbagai komponen ekosistem laut dan kemudian terakumulasi oleh organisme dari sumber alam (Marsden dan Rainbow, 2004). Banyak penelitian telah dilakukan pada akumulasi logam pada berbagai spesies seperti Dicentrarchus labrax and Mugil cephalus (Dural et al., 2007), kerang hijau P. viridis (Cordova et al., 2011), dan European catfish Silurus glanis (Squadrone et al., 2013).

Merkuri ( $\mathrm{Hg}) \quad$ bersifat mutagen, teratogen dan karsinogen, dengan toksisitas dan dampak lingkungan bervariasi dengan bentuk merkuri, dosis, rute konsumsi, jenis, jenis kelamin dan usia yang terpapar. Metil merkuri adalah bentuk yang paling beracun. Merkuri anorganik adalah Methylated primer oleh bakteri baik secara anaerob maupun aerobik. Senyawa merkuri organik lebih mudah diserap dan diekskresikan dengan buruk dibandingkan dengan bentuk anorganik. 
Akumulasi logam berat pada biota perairan dipengaruhi oleh berbagai faktor. Diantaranya adalah ukuran, stadium perkembangan dan kadar garam pada toksisitas logam berat terhadap organisme laut dan muara (Grossel et al., 2007). Organisme pada tingkat trofik berbeda akan menunjukkan respon akumulasi logam berat yang berbeda pada tubuhnya.Oleh karena itu, tujuan penelitian ini adalah untuk mengetahui bioakumulasi logam berat merkuri $(\mathrm{Hg})$ di musim hujan pada budidaya kerang hijau (P. viridis) untuk menilai risiko kesehatan masyarakat yang terkait dengan konsumsi kerang dari daerah ini dengan membandingkan kandungan logam berat yang dapat ditolerir seperti yang direkomendasikan oleh berbagai pihak.

\section{METODE PENELITIAN}

\section{Alat dan Bahan}

Alat yang digunakan pada penelitian ini adalah botol kaca ukuran $100 \mathrm{ml}$, botol sampel plastik volume $25 \mathrm{rnl}$; Plastik, cool box, es batu, dan Atomic Absorption
Spectrophotometer (AAS). Data yang diambil pada penelitian ini adalah kadar logam berat $\mathrm{Hg}$ pada air, kerang hijau, dan air.

Pengambilan Sampel Air Laut, Sedimen, dan Kerang Hijau (P. viridis)

Sampel air, sedimen dan kerang hijau P. viridis diambil dari tempat budidaya kerang hijau perairan bondet Cirebon yaitu sekitar $2 \mathrm{~km}$ dari pantai. Sampel diambil pada musim hujan dibulan Februari pada usia panen yaitu usia 6 bulan pemeliharaan. Sampel air laut, sedimen, dan kerang hijau diambil sebanyak 3 kali ulangan. Sampel air laut diambil pada lapisan permukaan $(30 \mathrm{~cm}$ di bawah per mukaan laut) dan dimasukkan ke dalam botol kaca (volume $\pm 100 \mathrm{ml}$ ). Sampel sedimen diambil dari dasar perairan tepat di bawah bagan tancap tempat budidaya kerang hijau. Sampel kerang diambil sebanyak tiga ekor pada setiap ulangan. Setelah itu sampel air, sedimen dan kerang hijau dimasukkan ke dalam Cool box selama transportasi ke laboratorium. Sampel 
dimasukkan ke dalam botol dan diukur di laboratorium Balai Pengujian dan Pembinaan Mutu Hasil Perikanan (BPPMHP) Cirebon, Jawa Barat untuk dilakukan pengukuran kadar logam berat merkuri $(\mathrm{Hg})$.

\section{Pengujian Logam Berat Mercuri (Hg) SNI 01-2354.6-2006}

Pengujian logam berat merkuri (Hg) mengikuti SNI 01-2354.6-2006. Sampel dihomogenisasi dengan cara diblender. Sampel basah ditimbang sebanyak 5 gram (dalam labu alas bulat). Sampel ditambahkan vanadium oxide (0,015-0,02 gram). Kemudian sampel ditambahkan batu didih 4-5 butir. Labu dan tabung kondensor dipasang beserta pemanas (mantel heating) di dalam ruang asam. Setelah itu sampel diberi $10 \mathrm{ml} \mathrm{H}_{2} \mathrm{SO}_{4}$ (95\%97\%) dan $10 \mathrm{ml} \mathrm{HNO}_{3}$ 65\%. Mantel heating dinyalakan paa suhu $60^{\circ} \mathrm{C}-$ $100^{\circ} \mathrm{C}$ (suhu dinaikkan secara bertahap). Sampel ditambahkan 4 tetes $\mathrm{H}_{2} \mathrm{O}_{2} 30 \%$ ke dalam labu. Suhu sampel dibiarkan turun sampai terjadi perubahan warna menjadi hijau cerah/jernih. Tabung sampel dilepaskan dari kondensor. Kemudian larutan sampel disaring dengan kertas saring ke dalam labu $50 \mathrm{ml}$. Pembacaan sampel dilakukan dengan alat AAS (GBC Avanta 932 AA).

\section{HASIL DAN PEMBAHASAN}

Berdasarkan hasil penelitian, diketahui konsentrasi $\mathrm{Hg}$ tertinggi terdapat pada kerang hijau yaitu sebesar $0.027 \pm 0.038$ ppm. Kemudian diikuti dengan konsentrasi $\mathrm{Hg}$ pada air yaitu sebesar $0.017 \pm 0.029 \mathrm{ppm}$. Sedangkan konsentrasi terendah terdapat pada sedimen yaitu sebesar $0.003 \pm 0.006$ ppm (Gambar 1).

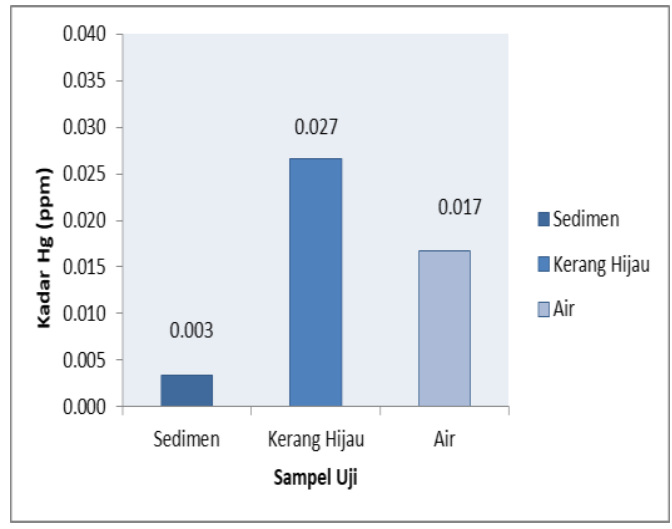

Gambar 1. Kadar logam berat merkuri pada sedimen, kerang hijau P. viridis, dan air. 
Pada penelitian ini terlihat bahwa konsentrasi logam berat $\mathrm{Hg}$ baik yag terdapat di dalam sedimen, dan air berada diluar ambang batas. Konsentrasi tersebut melebihi ambang batas minimal yang telah ditetapkan Pemerintah melalui Peraturan Pemerintah no.82 tahun 2001 yaitu 0,001 ppm. FDA menetapkan kandungan merkuri maksimum adalah 0,005 ppm untuk air dan 0,5 ppm untuk makanan, sedangkan WHO (World Health Organization) menetapkan batas maksimum yang lebih rendah yaitu 0,0001 ppm untuk air. Sedangkan menurut Direktorat Jenderal Pengawasan Obat dan makanan (POM) No. 03725/SK/VII/89 tentang batas maksimum cemaran logam berat $\mathrm{Hg}$ adalah 0,5 ppm.

Adanya perbedaan konsentrasi pada sedimen, kerang hijau, dan air disebabkan karena adanya perbedaan kemampuan akumulasi logam berat Hg. Pada dasarnya logam berat yang masuk ke badan perairan akan mengalami proses absorbsi, adsorbsi, dan pengendapan (Connell dan Miller, 1995). Proses absorbsi dilakukan oleh biota akuatik, seperti rumput laut (Yulianto et al. 2006), kerang hijau (Cordova et al, 2011), dan ikan (Johari, 2009). Adsorbsi logam berat dilakukan oleh partikel-partikel tersuspensi dalam kolom air dan selanjutnya mengendap ke dasar perairan. Pada penelitian ini kadar logam berat $\mathrm{Hg}$ pada sedimen menunjukkan kadar yang paling kecil $0.003 \pm 0.006 \mathrm{ppm}$. Hasil ini berbeda dengan penelitian Weber et al. (2013) yang menunjukkan bahwa konsentrasi logam berat ( $\mathrm{Al}, \mathrm{As}, \mathrm{Cd}, \mathrm{Co}, \mathrm{Cr}, \mathrm{Cu}$, $\mathrm{Fe}, \mathrm{Zn}$ dan $\mathrm{Pb}$ ) tertinggi terdapat pada sedimen, kemudian diikuti oleh air, dan terendah terdapat pada ikan. Hal ini dapat disebabkan oleh kondisi perairan Cirebon yang terpapar hujan secara terus menerus. Sehingga sedimen mengalami up welling dan tercampur dengan badan air. Pada Penelitian Younis et al. (2015) menunjukkan bahwa beberapa jenis logam berat menunjukkan kadar yang lebih rendah pada musim dingin.

Terjadinya bioakumulasi logam berat ke dalam kerang hijau sangat dimungkinkan mengingat logam berat dapat dengan mudah dan cepat masuk ke dalam tubuh makhluk hidup. 
Tingginya kadar $\mathrm{Hg}$ pada daging kerang hijau diduga disebabkan oleh usia dan ukuran kerang hijau yang sudah besar (Tabel 1). Kerang hijau yang dijadikan sampel pada penelitian ini merupakan kerang hijau usia panen yaitu 5-6 bulan. Semakin lama usia kerang hijau, maka semakin tinggi kadar akumulasi logam beratnya. Sebagaimana penelitian Cordova et al., (2011), Konsentrasi Logam berat $\mathrm{Hg}$ pada usia budidaya 1-2 bulan, 3-4 bulan, adalah 5-6 bulan adalah 35,47 $\mu \mathrm{g} / \mathrm{g}, \quad 205,73 \mu \mathrm{g} / \mathrm{g}, \quad 209,82 \mu \mathrm{g} / \mathrm{g}$.

Tabel 1. Berat dan panjang kerang hijau sampel

\begin{tabular}{|c|c|c|c|}
\hline No & Ulangan & Panjang $(\mathbf{c m})$ & Berat (gram) \\
\hline 1 & 1 & 5 & 9.39 \\
\hline 2 & 1 & 4.7 & 8.03 \\
\hline \multirow[t]{3}{*}{3} & 1 & 4.8 & 7.37 \\
\hline & Rata-rata & 4.833 & 8.263 \\
\hline & Standar deviasi & 0.153 & 1.030 \\
\hline 4 & 2 & 5.1 & 8.77 \\
\hline 5 & 2 & 5.3 & 10.16 \\
\hline \multirow[t]{3}{*}{6} & 2 & 5.1 & 8.82 \\
\hline & Rata-rata & 5.167 & 9.250 \\
\hline & Standar deviasi & 0.115 & 0.788 \\
\hline 7 & 3 & 4.9 & 7.97 \\
\hline 8 & 3 & 5 & 8.14 \\
\hline \multirow[t]{3}{*}{9} & 3 & 4.9 & 7.37 \\
\hline & Rata-rata & 4.933 & 7.827 \\
\hline & Standar deviasi & 0.058 & 0.405 \\
\hline
\end{tabular}

Logam berat merkuri merupakan logam berat non esensial yang bersifat sangat toksik. Akumulasi logam berat tersebut dalam tubuh organisme termasuk manusia dapat menimbulkan keracunan, gangguan kesehatan sampai kematian. Persyaratan mutu kerang di Indonesia didasarkan pada keputusan menteri Pertanian no.701/Kpts/TP.830/10/1987 (Tabel 2). Dengan demikian, berdasarkan persyaratan mutu BPOM, dapat dikatakan bahwa kerang hijau yang dibudidaya pada lokasi penelitian masih aman untuk dikonsumsi dengan tetap memperhatikan jumlah konsumsi. Pada konsentrasi $\mathrm{Hg}$ yang sangat rendah terhadap kerang hijau, apabila dikonsumsi secara berlebihan dan terus-menerus dapat memberikan dampak negatif. 
Tabel 2. Persyaratan mutu kerang di Indonesia menurut keputusan menteri Pertanian no. 701/Kpts/TP.830/10/1987

\begin{tabular}{rlcc}
\hline Jenis Mutu & Satuan & Persyaratan Mutu \\
\hline 1. & Cemaran Logam & & \\
$-\quad$ Timah, maks & $\mathrm{mg} / \mathrm{kg}$ & 250,0 \\
$-\quad$ Timbal, maks & $\mathrm{mg} / \mathrm{kg}$ & 2,0 \\
$-\quad$ Arsen, maks & $\mathrm{mg} / \mathrm{kg}$ & 100,0 \\
- & Raksa, maks & $\mathrm{mg} / \mathrm{kg}$ & 0,5 \\
\hline
\end{tabular}

\section{KESIMPULAN}

Berdasarkan hasil penelitian, diketahui bahwa kandungan logam berat merkuri $(\mathrm{Hg})$ pada sedimen sebesar 0,003 $\pm 0,006 \mathrm{ppm}$, dan air $0,017 \pm 0,029$ ppm. telah melebihi ambang batas maksimal. Akan tetapi kadar Hg kerang hijau P. viridis yaitu sebesar $0,027 \pm 0,038 \mathrm{ppm}$ masih aman untuk dikonsumsi.

\section{UCAPAN TERIMA KASIH}

Penelitian ini merupakan bagian dari Penelitian Dosen Pemula (PDP) tahun 2017-2018 yang didanai oleh Kemenristekdikti. Ucapan terima kasih diberikan kepada pihak Kemenristekdikti dan semua rekan yang telah terlibat dalam penelitian.

\section{DAFTAR PUSTAKA}

BPOM. 2002. Merkuri dan Bahayanya Bagi Kesehatan. Jakarta.

Connel DW and Miller. 2006. Kimia dan Ekotoksikologi Pencemaran. Universitas Indonesia. Jakarta.
Cordova MR, Zamani NP, Yulianda F. 2011. Akumulasi Logam Berat pada Kerang Hijau (Perna viridis) di PerairanTeluk Jakarta. Jurnal Moluska Indonesia. 2(1): 1-8.

Dural M, Goksu MZL, Ozak AA. 2007. Investigation of Heavy Metal Levels in Economically Important Fish Species Captured from The Tuzla Lagoon. Food Chem, 102: 415-421.

Grosell M, Blanchard J, Brix K, Gerdes R. 2007. Physio logy is pivotal for interactions between salinity and acute copper toxicity to fish and invertebrates. Aqu.Toxicol. 84:162172.

Johari HS. 2009. Analisis Pencemaran Logam Berat $\mathrm{Cu}, \mathrm{Cd}$, dan $\mathrm{Pb}$ di Perairan Kabupaten Administrasi Kepulauan Seribu Provinsi Jakarta [tesis]. Bogor (ID): Institut Pertanian Bogor.

Marsden ID, Rainbow PS. 2004. Does the accumulation of tracemetals in crustaceans affect their ecology- the amphipod example?J. Exp. Mar. Biol. Ecol. 300, 373-408.

Squadrone S, Prearo M, Brizio, P, Gavinelli S, Pellegrino M, Scanzio T, Guarise S, Benedetto A, Abete MC. 2013. Heavy Metals Distribution in Muscle, Liver, Kidney and Gill of European Catfish (Silurus glanis) from Italian Rivers. Chemosphere, 90: 358-365.

Supriadi D. 2016.Kerang Hijau dan Racun Mematikan. www.radarcirebon.com [17 Juni 2017].

Turkmen M., Turkmen A, Tepe, Y, Ates A, Kkus GK. 2008. Determination of Metal Contaminations in Sea Foods from Marmara, Aegean and Mediterranean Seas: Twelve Fish Species. Food Chem, 108: 794-800. 
Weber P, Behr ER, Knorr CDL, Vendruscolo DS, Flores EMM, Dressler VI, Baldisserotto B. 2013. Metals in the Water, Sediment, and Tissues of Two Fish Species from Different Trophic Levels in a Subtropical Brazilian River. Microchemical Journal, 106: 61-66.

Younis EM, Al-Asgah NA, Abdel-Warith AWA, Al-Mutairi AA. 2015. Seasonal variations in the body composition and bioaccumulation of heavy metals in Nile tilapia collected from drainage canals in Al-Ahsa, Saudi Arabia. Saudi Journal of Biological Sciences, 22: 443-447.

Yulianto B, Ario R, Agung T. 2006. Daya Serap Rumput Laut (Gracillaria sp.) Terhadap Logam Berat Tembaga (Cu) Sebagai Biofilter. Jurnal Ilmu Kelautan, 11(2) 72-78. 